\title{
Economic value of trees in the estate of the Harewood House stately home in the United Kingdom
}

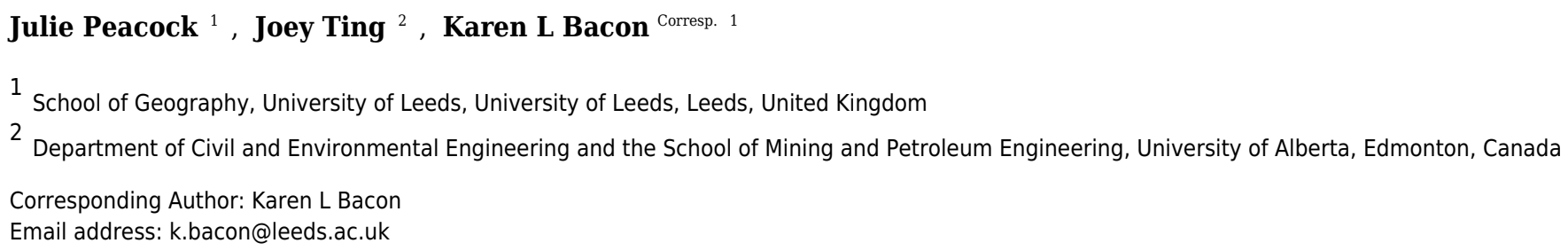

The estates of stately homes or manor houses are an untapped resource for assessing the ecosystem services provided by trees. Many of these estates have large collections of trees with clear value in terms of carbon storage, runoff prevention, and pollution removal along with additional benefits to biodiversity and human health. The estate of Harewood House in North Yorkshire represents an ideal example of such a stately home with a mixture of parkland and more formally planted gardens. The trees in each type of garden were analysed for height, diameter at breast height and light exposure. The data were then processed in iTrees software to generate economic benefits for each tree in both gardens. The analysis found that the larger North Front parkland garden had greater total benefits but the more densely planted formal West Garden had the greater per hectare value. In total, the trees on Harewood House estate are estimated to provide approximately $£ 29$ million in ecosystem service benefits. This study is the first to analyse the trees of stately homes for economic benefits and highlights that the trees are a valuable commodity for the estates. This should be considered in future planning and management of such estates. 
1 Economic value of trees in the estate of the Harewood House stately home in the United

2 Kingdom

3

4 Julie Peacock ${ }^{1}$, Joey Ting ${ }^{2}$ and Karen L. Bacon ${ }^{1 *}$

51 School of Geography, University of Leeds, Leeds, LS2 9JT, United Kingdom

62 Department of Civil and Environmental Engineering and the School of Mining and

7 Petroleum Engineering, University of Alberta, Edmonton, Canada

8

9 *Corresponding author:

10 Karen L. Bacon ${ }^{1}$

11 Email: k.bacon@leeds.ac.uk

12 


\section{Abstract}

The estates of stately homes or manor houses are an untapped resource for assessing the ecosystem services provided by trees. Many of these estates have large collections of trees with clear value in terms of carbon storage, runoff prevention, and pollution removal along with additional benefits to biodiversity and human health. The estate of Harewood House in North Yorkshire represents an ideal example of such a stately home with a mixture of parkland and more formally planted gardens. The trees in each type of garden were analysed for height, diameter at breast height and light exposure. The data were then processed in iTree software to generate economic benefits for each tree in both gardens. The analysis found that the larger North Front parkland garden had greater total benefits but the more densely planted formal West Garden had the greater per hectare value. In total, the trees in Harewood House estate are estimated to provide approximately $£ 29$ million in ecosystem service benefits. This study is the first to analyse the trees of stately homes for economic benefits and highlights that the trees are a valuable commodity for the estates. This should be considered in future planning and management of such estates.

Key words: Stately homes; manor houses; economic value; trees; ecosystem services; natural capital

\section{Introduction}

Ecosystem services refer to the services that ecological systems provide to humanity and numerous studies now attempt to put a financial value on such services in various ecosystems (Costanza et al., 1997; Costanza et al., 2014; de Groot et al., 2012). They can be considered from a local to a regional and even biome (Costanza et al., 1997; Bolund \& Hunhammar, 1999) scale and are increasingly considered in conjunction with the development and implementation of policy (Egoh et al., 2007; de Groot et al., 2010; Wolff, Schulp \& Verburg, 2015). The economic value and ecosystem service value of trees are increasingly well-studied in urban environments (e.g. Kowarik and von der Lippe, 2018; Nowak et al., 2010 and references therein; Luttik, 2000), 
including large cities such as London, UK (London iTree Report, 2015) and Chicago, USA (Nowak et al., 2010). These studies identified annual benefits derived from trees on the order of millions of pounds to the cities. For example, the trees of London were recently calculated to provide approximately $£ 126.1$ million in pollution removal value and $£ 4.76$ million per annum in carbon storage value (London iTree Report, 2015).

Similar studies focusing on non-urban terrestrial ecosystem in agricultural (Tscharntke et al., 2005) and forest ecosystems (Gamfeldt et al., 2013; Ninan \& Inoue, 2013) are also increasingly common and focus on a wide-range of ecosystem services such as human well-being (e.g. Fedele, Locatelli \& Djoudi, 2017), biodiversity (e.g. Mace, Norris \& Fitter, 2012) and carbon sequestration (e.g. Novara et al., 2017). One land-use type that does not currently feature in the ecosystem service literature is the estates of stately homes (sometimes also call manor homes). Stately homes are large houses that are or were occupied by landed gentry. In the United Kingdom, these houses and their often extensive grounds are now commonly open to the public as a means of generating income and may be located in rural areas or closer to city limits as cities have expanded since the houses were originally constructed. Many such grounds include a mixture of formally planted gardens, where both native and non-native trees and shrubs are grown for aesthetic purposes, and more open parkland environments. The gardens often preserve rare collections and varieties of different species, making them a useful conservation and research resource (Dosmann, 2016; Dosmann \& Groover, 2012; Hockenberry Meyer et al., 2010). Additionally, their often extensive array of ecosystems mean that many estates are important sites for local biodiversity (Šantrůčková et al., 2017; Ignatieva \& Konechnaya, 2004; Lohumus \& Liira, 2013). The grounds of stately homes, therefore, offer a currently untapped resource for considering the economic value of the trees in a managed ecosystem that often lies between rural and urban areas with a mixture of native and non-native species, similar to plant community composition along rural to urban gradients (Kowarik, 1990). Their positioning along the nexus of the urban-rural transition make them particularly interesting and offers a unique ecological placement for considering the value of the trees. With more and more of these properties meeting the costs of their upkeep by opening to the public and the expense of maintaining large parkland and gardens, the need to consider the ecosystem services and the potential economic value of their trees will become increasingly important. Considering the ecosystem services of stately homes and their estates has multiple potential benefits, including, 
86 raising the profile of the ecosystem service benefits of trees to the visiting public, providing a

87 clear justification for the cost of maintaining the gardens; demonstrating what the gardens

88

104

105

106

107

108

109

110

111

112

113

114

115 provide to the local environment and to the estates themselves; and showcasing the pollutioncapture benefit of the trees (particularly for stately homes near busy roads and close to urban centres).

Harewood House, the location for this study, is located approximately $14 \mathrm{~km}$ from Leeds city centre in Yorkshire, United Kingdom. The house is over 260 years old and was constructed between 1756 and 1771. It sits on a 400 hectare estate that includes the Grade 1 listed main house building and publicly accessible facilities including a bird garden, café, and playground as well as parkland and more formal gardens. Harewood House is a member of the Treasure Houses of England and one of the foremost English stately homes. The diversity of ecosystems, different land use, and proximity to a large urban centre while still being primarily rural makes the Harewood House estate an ideal location to investigate the economic value of trees in these unique environments.

To the authors' knowledge, this study provides the first such investigation of the economic benefits of the trees of stately homes. The aims of this study are (1) to determine the economic and ecosystem service value of trees in Harewood House and (2) to investigate if this differed between a parkland and a formal garden environment.

\section{Materials \& Methods}

One parkland (the North Front) and one formal garden (the Western Garden) within the Harewood House estate were selected as representative of the two main types of land use within the estate for analysis. The North Front covers an area of 8.68 ha and the West Garden has an area of 0.98 ha. Both gardens were investigated to determine species composition and ecosystem service provision. All of the trees in both gardens (66 in the North Front and 57 in the West Garden) were identified to species level and measured for diameter at breast height (DBH), tree height, crown height, and light exposure measured by determining how many faces of the crown are exposed to light between 0 and 5). These data were then input to the iTree Eco programme (https://www.itreetools.org/) to calculate the economic value of each individual tree in terms of structural value, carbon storage, carbon sequestration, avoided runoff, pollution removal and 
116 energy savings using the methods outlined in both the iTree Eco programme and in the London

117 iTree Report (2015). In summary, the iTree Eco programme utilises measurements to calculate

118 both total and annual economic values for the various outputs using reference data sets and

119 standard equations based on the relationships of the simple plant measurements and the

120 economic values. Measurements are separated by the programme into two sections, mandatory

121 and recommended (i-Tree manual, 2017). Mandatory data are measurements that must be taken

122 and inputted into the program for it to run, including DBH and species of tree. Recommended

123 data are measurements that should be taken if possible, but are not required for the programme to

124 run successfully. If the recommended data are not inputted, i-Tree Eco will estimate a value

125 based on the DBH and species of the tree but the estimated value will not be as accurate as an

126 actual measured value. Recommended data collected as part of this study were height of tree,

127 height of canopy, size of canopy, light exposure, percent dieback, percent of crown missing, and

128 land use type (i-Tree manual, 2017). We also recorded GPS locations for all trees, tree identity

129 tag numbers, angle to bottom of canopy, height of canopy with respect to 0 degrees and height of

130 canopy bottom (see supplemental material). Data collection was undertaken during July and

131 August 2017.

132 All statistical data analysis was conducted using PAST version 3.15 and figures were prepared

133 using SigmaPlot13. All data were tested for normality using the Anderson-Darling A test (all

134 were non-normally distributed $\mathrm{p}<0.05$ ) and Mann Whitney $U$ tests were used to test for

135 difference to investigate non-normal data from the two gardens. The supplementary material file

136 provides all raw data used in the analyses.

\section{Results}

139

(i) Composition of gardens

140 The North Front and the West Garden showed an array of differences in terms of their species

141 composition and character. Table 1 summarises the diversity measures for both gardens and

142 highlights that the West Garden has a higher richness and greater diversity than the North Front.

143 There was also a difference in the density of trees between the two sites, with the North Front

144 having 7.60 trees per hectare and the West Garden having 58.16 trees per hectare. There is a 
145 moderate turnover of species between the two gardens (Whittaker's Beta $\mathrm{W}=0.40$ ) and the West

146 Garden contains 6 of the 11 species in the North Front. Figure 1 shows the difference in relative

147 abundance of each species planted in both gardens. The North Front has 11 species and is

148 dominated by Quercus robur, which accounts for over $50 \%$ of the trees in this garden. The

149 remaining $50 \%$ is split between several species at much lower abundance $(<15 \%$ each),

150 including Cedrus libani, Fagus sylvatica, Castanea sativa, Cedrus atlantica glauca, Cedrus

151 atlantica, and Fagus sylvatica 'Purpurea' and other species at $<2 \%$ abundance (one tree

152 recorded in the garden). Species richness is greater in the West Garden (26 species), and there is

153 a greater spread of relative abundance between species. The most common species remains

154 Quercus robur but at a much reduced abundance ( $19 \%$ of trees in the garden) and with a larger

155 array of species making up the rest of the garden's trees, all at just over $12 \%$ or lower abundance.

156 Rhododendron ponticum, Acer patmatum, Betuala pendula, and Cupressocyparis leylandii are

157 the next most abundant species in the West Garden and none account for more than $12.2 \%$ of the

158 trees in this garden.

159 (ii) Tree characteristics

160 The trees in the North Front are significantly $(\mathrm{p}<0.05)$ taller than those of the West Garden

161 (Figure 2a). DBH is also significantly greater $(\mathrm{p}<0.005)$ in the North Front (Figure $2 b)$ with

162 median height vales of trees in West Garden below the lower quartile of the trees in the North

163 Front. The trees in the North Front have higher light exposure than those in the West Garden

164 (Figure 2c). There are three trees with only one face receiving light in the West Garden but none

165 in the North Front receiving so little light. In addition, in the North Front there are 18 trees with

166 all five sides exposed to light whereas there are just three trees that receive this level of light in

167 the West Garden.

168 In addition to raw DBH analysis, size classes of DBH also differed considerably between the two

169 gardens. Figure 3 shows the size class distribution of the trees in the North Front (black) and the

170 West Garden (grey). The North Front has very few individual trees in the lower size classes with

171 only five trees between $7 \mathrm{~cm}$ and $20 \mathrm{~cm}$. The West Garden has more, with 15 trees in these small

172 size classes. Both gardens have the majority of individuals in size classes between $60 \mathrm{~cm}$ and

$173100 \mathrm{~cm}$.

174 (iii) Ecosystem services 
175 Ecosystem service values were calculated for all measured trees in both gardens. The trees in the

176 North Garden have a greater value, in terms of structure, carbon storage, and total annual

177 benefits than the trees in the West Garden. However, per hectare, the West Garden's trees have

178 greater value. For the West Garden, nine trees with DBHs greater than $100 \mathrm{~cm}$ account for both

$17945 \%$ of the structural and carbon value and $31 \%$ of the total annual benefits. In the North Front

180 trees with a DBH greater than $100 \mathrm{~cm}$ account for $32 \%$ and the value (structural and carbon

181 storage) and 24\% of the annual total benefits. However, if all trees with a DBH greater than 90

$182 \mathrm{~cm}$ are included they account for $73 \%$ of the value (structural and carbon storage) and $67 \%$ of

183 the annual total benefits. Detailed iTree output data are provided in Supplementary Material.

\section{Discussion}

(i) Composition of Gardens

187

The cultural value of stately homes is well known and described (Cranz \& Boland, 2004) with most stately homes highlighting their particular contribution to local cultural history in various manners through exhibitions and permanent displays. However, the ecological value, both in terms of biodiversity and ecosystem services (see below), are far less well studied (Lohumus \& Liira, 2013). Both gardens provide habitat for various plants and animals and the higher biodiversity of the West Garden may be seen as a positive thing for wildlife. Quercus robur, the dominant species for both gardens has a high wildlife value, in terms of invertebrate populations, seeds to provide food, nesting space and fungal populations, although it has a low value to wildlife for pollen and nectar (Alexander, Butler \& Green, 2006). This is similar to Fagus sylvatica and Castanea sativa, which both have high abundance in the North Front and are also found in the West Garden. Aesculus hippocastanum and Crataegus monogyna have individuals represented in the North Front with a high value to wildlife for pollen and nectar. In the west garden there are a wide range of species with a high wildlife value for both fruits and seeds and pollen and nectar including Sorbus aucuparia, Tilia platyphyllos, Ilex aquifolium, and Prunus pissardii (Alexander, Butler and Green, 2006). Other species in the West Garden have limited value for wildlife including Cupressocyparis leylandii and Rhododendron ponticum, although $R$. ponticum does attract and sustain pollinating insects (Stout, 2007). It is likely that the different species and different planting arrangements of the two gardens may support slightly different 
205 niches and increase overall biodiversity of the estate similar to the suggestions of Sjöman et al.,

206 (2016), but this was beyond the scope of the current study to investigate.

207 (ii) Ecosystem service value

208 This study identified a total of over $£ 7$ million for the structural and carbon storage value and 209 over $£ 1,000$ of annual benefits for the two gardens within Harewood House. The formal West

210 Garden had a higher value per unit area but the larger North Front parkland garden had a higher

211 value overall. Both gardens together account for approximately $2.4 \%$ of the Harewood estate

212 area and represent contrasting planting regimes - a lower density regime represented by the

213 North Front and a higher density regime represented by the West Garden. Therefore, a

214 conservative estimate of the total value provided by the trees to the Harewood House estate can

215 be calculated by considering the average per area value of the two gardens and multiplying up to

216 the entire estate area. This suggests that the total value to Harewood House of the trees is over

$217 £ 29$ million for structural and carbon storage values and over $£ 48 \mathrm{~K}$ of annual benefits. The North

218 Front represents a low tree density part of the estate and the West Garden represents a high-

219 density planting part of the estate. Therefore, the average value of the two gardens per unit area

220 represents a conservative estimate of the potential total value of trees to the estate.

221 Per hectare, the carbon storage values of the West Garden is far greater than the North Front.

222 Harewood House estate is not a rural forest or plantation, nor is it a suburban or urban area.

223 Therefore, it can be expected that the carbon storage values of the trees might sit somewhere

224 between values previously reported for rural and urban environments. The North Front carbon

225 storage value is below that reported as the average urban forest carbon storage density of 21.1

$226 \mathrm{tC} / \mathrm{ha}$ and the average forest stand of $53.3 \mathrm{tC} / \mathrm{ha}$ in the USA (Nowak \& Crane, 2002) at 16.942

$227 \mathrm{tC} /$ ha whereas the West Garden, at $80.047 \mathrm{tC} / \mathrm{ha}$, exceeds both estimates.

228 Dewar \& Canell (1992) suggested that carbon storage in UK plantations ranged from

229 approximately $40-80 \mathrm{tC} / \mathrm{ha}$. This varied with species and thinning regime, but highlights that

230 the North Front is below this average range in terms of carbon storage and the West Garden is at

231 the very high end of the range for the UK.

232 Strohbach \& Haase (2012) examined the range of carbon storage values across the city of

233 Leipzig, Germany and found that the average carbon storage was $11.8 \mathrm{Mg} \mathrm{C}$ per hectare. The 
234 highest carbon storage was identified in areas of the city with $98.26 \mathrm{MgC} / \mathrm{ha}$ in areas of riparian

235 forest and the lowest of $\sim 4 \mathrm{MgC} /$ ha in areas with multi-story housing. Other studies have

236 identified similar ranges for urban trees included Barcelona, Spain, at 11.2 average and 33.3

237 maximum (Chaparro \& Terradas, 2009), Chicago, USA, at 14.1 average and 35.8 maximum

238 (Nowak, 1994), Leicester, UK at 31.6 average and 288.6 maximum (Davis et al., 2011), and

239 Hangzhou, China at 30.3 average (Zhao et al., 2010). This shows that the values calculated for

240 Harewood House fall easily within the range of urban tree carbon storage and, for the West

241 Garden, can be much higher than the average value for urban trees. The average values of

242 Harewood House for carbon storage fall within or exceed these ranges, showing that the estates

243 of stately homes can be a valuable carbon store, in addition to their ecological and cultural value.

244 The trees in Harewood House also provide significant carbon sequestration, pollution removal

245 and runoff reduction (Tables 2 and 3, Supplementary Material).

246 The distribution of trees into different size classes (Figure 3) shows that Harewood House has a

247 greater proportion of trees in larger (over $60 \mathrm{~cm} \mathrm{DBH})$ size classes than the smaller $(20 \mathrm{~cm}$ or

248 smaller) classes. In the North Front $68.1 \%$ of trees and $42.1 \%$ of trees in the West Garden have

$249 \mathrm{DBH}$ of at least $60 \mathrm{~cm}$. These trees are likely to be older and, usually, mature with some over

250100 years old. When compared to the size class distribution of trees in London (see Figure 6 in

251 London iTree Report, 2015) it is clear that the trees in Harewood House have a very different

252 distribution across DBH size classes. Proportionally, there are far more trees in larger DBH size

253 classes and far fewer smaller trees in Harewood House than in London. This suggests that

254 Harewood House, and likely other similar stately homes with large estates, may provide a niche

255 for the preservation of particularly large trees. Such trees have a significant and often

256 disproportionate carbon-storage value (Diaz-Porras, Gaston \& Evans, 2014) and are also likely to

257 have additional ecological and cultural value. Contrastingly, the few, and in the case of the

258 North Front very few, numbers of trees in the smaller DBH size classes may raise concerns for

259 the long-term sustainability of the ecological and economic benefits of trees in the estate. This

260 also suggests that the unique niche for larger, economically and ecologically valuable trees, may

261 become reduced in the mid-term future. There is little regeneration of trees in either garden and

262 the middle size classes are also quite sparse. This suggests that the planting of young trees should

263 be prioritised while the larger trees are managed to ensure that they continue to provide carbon

264 storage and other economic and ecological services for decades to come. These findings also 
265 highlight a clear management use for the iTree Eco programme and the use of similar approaches 266 for future management of the estates of stately homes. This information could be useful in the 267 future management of the estate by helping to inform decisions about which species to plant and 268 if some trees do need to be removed, which species should be targeted and which avoided. A 269 comparison to the full ecological value of the trees (e.g. provision of ecosystem and habitat for 270 other organisms, impact on soil quality, among other services) is needed to supplement the 271 economic information for a fully informed management system.

272 Previous assessments of the natural value of stately homes has been largely descriptive 273 (Halbrooks, 2005; Nestor \& Mann, 1998) or semi-quantitative (Walerzak et al., 2015). Walerzak 274 et al., (2015) highlight the necessity of being able to compare between studies and estates to fully 275 understand the value and conservation requirements across a range of such properties. They 276 propose a semi-quantitative approach that provides a numeric value for the value of the estate but 277 do not fully consider the economic value of the natural capital within such estates. The iTree 278 approach, while not considering the ecological value of the estates, provides a simple,

279 280 reproducible and efficient method to generate economic values for the trees on these estates. The values presented in Tables 2 and 3 (and Supplementary Material) clearly show the economic value of the trees in the two gardens at Harewood House. They also show the difference between the two types of garden - the more densely planted West Garden had a greater per hectare value but the larger parkland garden of the North Front provides greater economic value overall. The findings suggest that a maximised economic value of planting could likely be achieved by increasing the density of planting in more areas of the estate; however, this would need to be balanced against the growth and maintenance of the larger trees $(\mathrm{DBH}>60 \mathrm{~cm})$ and the ecological and cultural values of the parkland. This approach provides clear data that can be compared easily between sites and, if used in conjunction with ecological data, could provide a valuable estimate of the value of the estates of stately homes.

\section{Conclusions}


294 The trees of the North Front and West Garden at Harewood House estate provide a range of

295 important ecosystem services that amount to approximately $£ 1,165$ per year. This value is in

296 addition to ecosystem provision and support of biodiversity on the estate and the well-

297 documented health benefits of natural and parkland environments to people. This study shows

298 that the economic value of trees in the estates of stately homes is not trivial and should be

299 considered as part of the planning and management of such estates, and potentially, as part of the

300 assessment of carbon budgets of local authorities and perhaps on larger scales across the country.

301

302 Acknowledgements

303 The authors would like to acknowledge Mr Trevor Nicholson, Head Gardener for the Harewood

304 House Trust, for assistance with fieldwork and helpful discussion and Lord David Lascelles, 8th

305 Earl of Harewood for permission to undertake fieldwork on the Harewood House estate. Data for 306 DBH of London trees was provided by Treeconmics and Forest Research.

307

308

\section{References}

309 Alexander K, Butler J and Green T. 2006. The value of different tree and shrub species to 310 wildlife. British Wildlife 18: 18-28.

311 Bolund, P and Hunhammar, S. 1999. Ecosystem services in urban areas. Ecological Economics 312 29: 293-301.

313 Chaparro L and Terradas J. 2009. Ecological services of urban forest in Barcelona. Centre de 314 Recerca Ecological I Aplicacions Forestals.

315 Costanza R, D'Arge R, De Groot R, Faber S, Grasso M, Hannon B, Limburg K, Naeem S, 316 O'Neill RV, Paruelo J, Raskin RG, Sutton P, Van Den Belt M. 1997. The value of the world's 317 ecosystem services and natural capital. Nature 387: 253-260.

318 Costanza R, de Groot R, Sutton P, van der Ploeg S, Anderson SJ, Kubiszewski I, Farber S, 319 Turner RK. 2014. Changes in the global value of ecosystem services. Global Environmental 320 Change 26: 152-158. 
321 Cranz G and Boland M. 2004. Defining the sustainable park: a fifth model for urban parks.

322 Landscape Journal 23: 102-120.

323 Davis ZG, Edmondson JL, Heinemeyer A, Leake JR, Gaston KJ. 2011. Mapping an urban

324 ecosystem service: quantifying above-ground carbon storage at a city-wide scale. Journal of 325 Applied Ecology 48: 1125-1134.

326 de Groot RA, Aikemade L, Braat L, Hein L, Willemen L. 2010. Challenges in integrating the 327 concept of ecosystem services and values in landscape planning, management and decision 328 making. Ecological Complexity 7: 260-272.

329 de Groot RA, Brander L, der Ploega S, Contaszac R, Bernard F, Braate L, Christie M, Crossman 330 N, Ghermandii A, Heina L, Hussain S, Pushpam J, Kumark, McVittie A, Portelal R, Rodriguez 331 LC, Brinkm P, Beukering P. 2012. Global estimates of the value of ecosystems and their 332 services in monetary units. Ecosystem Services 1: 50-61.

333 Dewar RC and Canell MGR. 1992. Carbon sequestration in the trees, products and soils of forest 334 plantations: an analysis using UK examples. Tree Physiology 11: 49-71.

335 Diaz-Porras DF, Gaston KJ, Evans KL. 2014. 110 years of change in urban tree stocks and 336 associated carbon storage. Ecology and Evolution 4: 1413-1422.

337 Dosmann MS and Groover A. 2012. The importance of living botanical collections for plant 338 biology and the "next generation" of evo-devo research. Frontiers in Plant Science 3: 137.

339 Dosmann MS. 2006. Research in the Garden: Averting the Collections Crisis. Botanical Review $340 \quad 72: 207-234$.

341 Egoh B, Rouget M, Reyers B, Knight AT, Cowling RM, van Jaarsveld AS, Welz A. 2007.

342 Integrating ecosystem services into conservation assessments: A review. Ecological Economics 343 63: 714-721.

344 Fedele G, Locatelli B, Djoudi H. 2017. Mechanisms mediating the contributions of ecosystem 345 services to human well-being and resilience. Ecosystem Services 28: 43-54.

346 Gamfeldt L, Snall T, Bagchi R, Jonsson M, Gustafsson L, Kjellander P, Ruiz-Jan MC, Froberg 347 M, Stendahl J, Philipson CD, Mikusinski G, Andersson E, Westerlund B, Andren H, Moberg F, 
348 Moen J, Bergtsson J. 2013. Higher leves of multiple ecosystem services are found in forests with 349 more tree species. Nature Communications 4: 1340.

350 Halbrooks MC. 2005. The English garden at Stan Hywet Hall and Gardens: Interpretation, 351 analysis and documentation of a historic garden restoration. Horticultural Technology 15: 196352213.

353 Hockenberry Meyer M, Hokanson S, Galatowitsch S, Luby J. 2010. Public gardens: fulfilling the 354 university's research mission. Horticultural Technology 20: 522-527.

355 Ignatieva M and Konechnaya G. 2004. Floristic investigations of historical parks in St

356 Petersburg, Russia. Urban Habitats 2: 174-216.

357 iTree website available at https://www.itreetools.org/

358 iTree Eco Manual. 2017. version 5 available at https://www.itreetools.org/resources/manuals.php

359 Kowarik I.1990. Some responses of flora and vegetation to urbanization in Central Europe. In 360 Sukopp H and Hejny S, eds. Urban Ecology: Plants and Plant Communities in Urban

361 Environments SPB Academic Publishing, 45-74.

362 Kowarik I and von der Lippe M. 2018. Plant population success across urban ecosystems: A

363 framework to inform biodiversity conservation in cities. Journal of Applied Ecology [early

364 online] DOI: https://doi.org/10.1111/1365-2664.13144

365 Lohumus K and Liira J. 2013. Old rural parks support higher biodiversity than forest remnants.

366 Basic Applied Ecology 14: 165-173.

367 London iTree Report. 2015 Valuing London's Urban Forest: Results of the London i-Tree Eco 368 Project. Treeconomics London. ISBN 978-0-9571371-1-0.

369 Luttik J. 2000. The value of trees, water and open spaces as reflected by house prices in the 370 Netherlands. Landscape and Urban Planning 76: 161-167.

371 Mace GM, Norris K, Fitter AH. 2012. Biodiversity and ecosystem services: a multi-layered 372 relationship. Trends in Ecology \& Evolution 27: 19-26.

373 Nestor BA and Mann WA. 1998. An archival restoration of the horticultural and design elements 374 of Barnsley Gardens, Georgia. Landscape and Urban Planning 42: 107-122. 
375 Ninan N and Inoue M. 2013. Valuing forest ecosystem services: What we know and what we 376 don't. Ecological Economics 93: 137-149.

377 Novara A, Gristina L, Sala G, Galati A, Crescimanno M, Cerda, A, Badalamenti E, La Mantia T. 378 2017. Agricultural land abandonment in Mediterranean environment provides ecosystem services 379 via soil carbon sequestration. Science of the Total Environment 576: 420-429.

380 Nowak DJ and Crane DE. 2002. Carbon storage and sequestration by urban tress in the USA. 381 Environmental Pollution 116: 381-389.

382 Nowak DJ. 1994. Urban forest structure: the state of Chicago's urban forest. USDA Forest 383 Services General Technical Report NE-186.

384 Nowark DJ, Stein SM, Randler PB, Greenfield EJ, Comas SJ, Carr, MA, Alig RJ. 2010.

385 Sustaining America's urban trees and forests. United States Department of Agriculture Forest 386 Service. General Technical Report NRS-62.

387 Šantrůčková M, Demková K, Dostálek J, Frantík T. 2017. Manor gardens: Harbors of local 388 natural habitats? Biological Conservation 205: 16-22.

389 Sjöman H, Morgenrothc J, Sjömana JD, Sæbø A, and Kowarike I. 2016. Diversification of the 390 urban forest - Can we afford to exclude exotic tree species? Urban Forestry \& Urban Greening 391 18: 237-241.Stout JC. 2007. Pollination of invasive Rhododendron ponticum (Ericaceae) in 392 Ireland. Apidologie 38: 198.

393 Strohbach M and Haase D. 2012. Above-ground carbon storage by urban trees in Leipzig, 394 Germany: Analysis of patterns in a European city. Landscape and Urban Planning 104: 95-104.

395 Tscharntke T, Klein AM, Kruess A, Steffan-Dewenter I, Thies C. 2005. Landscape perspectives 396 on agricultural intensification and biodiversity - ecosystem service management. Ecological 397 Letters 8: 857-874.

398 Walerzak MT, Swierk D, Krzyzaniak M, Urbanski P. 2015. A method of analysis and 399 valorisation of historic green space arrangement in rural areas in Poldan. Bulgarian Journal of 400 Agricultural Science 21: 507-516. 
401 Wolff S, Schulp CJE, Verburg PH. 2015. Mapping ecosystem services demand: A review of 402 current research and future perspectives. Ecological Indicators 55: 159-171.

403 Zhao M, Kong Z-H, Escobedo FJ, Gao J. 2010. Impacts of urban forests on offsetting carbon 404 emissions from industrial energy use in Hangzhou, China. Journal of Environmental 405 Management 91: 807-813.

406

407 


\section{Table $\mathbf{1}$ (on next page)}

Diversity descriptive data comparing the North Front and West Garden. Whittaker's Beta $\mathrm{W}$ for the two gardens is $\mathbf{0 . 4}$, denoting a high turnover of species between the two gardens. 
1

2

\begin{tabular}{l|l|l} 
& North Front & West Garden \\
\hline Total individuals & 66 & 57 \\
Species richness & 11 & 26 \\
Shannon-Wiener H' & 1.67 & 2.89
\end{tabular}

3 
Table 2 (on next page)

Total benefits of the trees for the North Front and West Garden. 


\begin{tabular}{|c|c|c|c|c|c|c|c|c|c|c|c|}
\hline & \multirow[t]{2}{*}{$\begin{array}{r}\text { Number of } \\
\text { trees }\end{array}$} & \multirow{2}{*}{$\begin{array}{r}\begin{array}{r}\text { Structural } \\
\text { Value }\end{array} \\
\text { (f) }\end{array}$} & \multicolumn{2}{|c|}{ Carbon Storage } & \multicolumn{2}{|c|}{$\begin{array}{r}\text { Gross Carbon } \\
\text { Sequestration }\end{array}$} & \multicolumn{2}{|c|}{ Avoided Runoff } & \multicolumn{2}{|c|}{$\begin{array}{l}\text { Pollution } \\
\text { Removal }\end{array}$} & \multirow{2}{*}{ 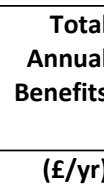 } \\
\hline & & & (kg) & (f) & (kg/yr) & $(f / y r)$ & $\left(\mathrm{m}^{3} / \mathrm{yr}\right)$ & (f/yr) & (kg/yr) & (f/yr) & \\
\hline North Front & 66 & $447,918.08$ & $147,058.82$ & 9411.79 & 3005.00 & 192.35 & 154.63 & 124.78 & 75.05 & 496.70 & 816.55 \\
\hline West Garden & 57 & $238,989.56$ & $7,8446.80$ & 5020.56 & 1553.00 & 99.41 & 61.57 & 49.96 & 30.01 & 199.53 & 348.86 \\
\hline
\end{tabular}

1 


\section{Table 3 (on next page)}

Per hectare benefits of the trees in the North Front and West Garden. 


\begin{tabular}{|c|c|c|c|c|c|c|c|c|c|c|c|}
\hline & \multirow{2}{*}{$\begin{array}{r}\text { Numbe } \\
r \text { of } \\
\text { trees }\end{array}$} & \multirow{2}{*}{$\begin{array}{r}\text { Structural } \\
\text { Value/ha } \\
\text { (f) }\end{array}$} & \multicolumn{2}{|c|}{ Carbon Storage/ha } & \multicolumn{2}{|c|}{$\begin{array}{r}\text { Gross Carbon } \\
\text { Sequestration/ha }\end{array}$} & \multicolumn{2}{|c|}{$\begin{array}{r}\text { Avoided } \\
\text { Runoff/ha }\end{array}$} & \multicolumn{2}{|c|}{$\begin{array}{r}\text { Pollution } \\
\text { Removal/ha }\end{array}$} & \multirow{2}{*}{$\begin{array}{r}\text { Total } \\
\text { Annual } \\
\text { Benefits/h } \\
\mathrm{a} \\
(\mathbf{f} / \mathrm{yr})\end{array}$} \\
\hline & & & (kg) & (f) & $(\mathrm{kg} / \mathrm{yr})$ & $(f / y r)$ & $\begin{array}{r}\left(m^{3} / y r\right. \\
)\end{array}$ & $(£ / y r)$ & $\begin{array}{r}(\mathrm{kg} / \mathrm{yr} \\
)\end{array}$ & $(f / y r)$ & \\
\hline North Front & 66 & $\begin{array}{r}5,1603.4 \\
7\end{array}$ & $\begin{array}{r}16,942.2 \\
6\end{array}$ & $\begin{array}{r}1084.3 \\
1\end{array}$ & 346.20 & 22.16 & $\begin{array}{r}17.8 \\
1\end{array}$ & $\begin{array}{r}14.3 \\
8\end{array}$ & 8.65 & 57.22 & 94.07 \\
\hline $\begin{array}{l}\text { West } \\
\text { Garden }\end{array}$ & 57 & $\begin{array}{r}24,3866 . \\
9\end{array}$ & $\begin{array}{r}80,047.7 \\
6\end{array}$ & $\begin{array}{r}5123.0 \\
2\end{array}$ & $\begin{array}{r}1584.6 \\
9\end{array}$ & $\begin{array}{r}101.4 \\
4\end{array}$ & $\begin{array}{r}62.8 \\
3\end{array}$ & $\begin{array}{r}50.9 \\
8\end{array}$ & $\begin{array}{r}30.6 \\
2\end{array}$ & $\begin{array}{r}203.6 \\
0\end{array}$ & 355.98 \\
\hline
\end{tabular}

1 
Figure 1

Relative abundance (\%) of trees in (a) the North Front parkland and (b) the West Garden 


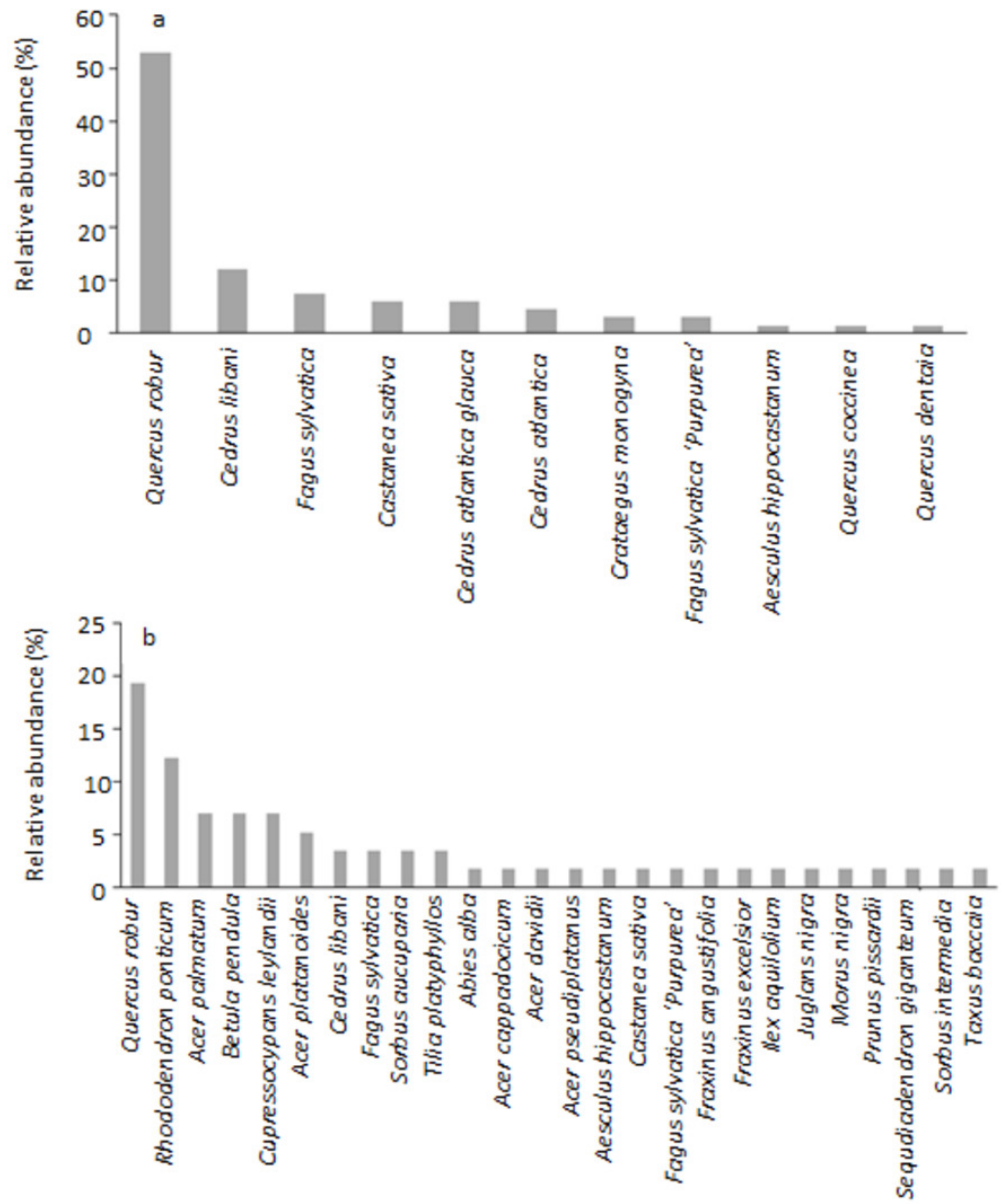


Figure 2

Tree characteristics and differences between the North Front and West Garden: a) Tree height $(z=-2.13, \mathrm{P}<0.05)$; b) $\mathrm{DBH},(\mathrm{z}=-3.66, \mathrm{P}<0.0005) ; \mathrm{c})$ sides of canopy exposed to light $(z=-4.11, P=0.0001)$.
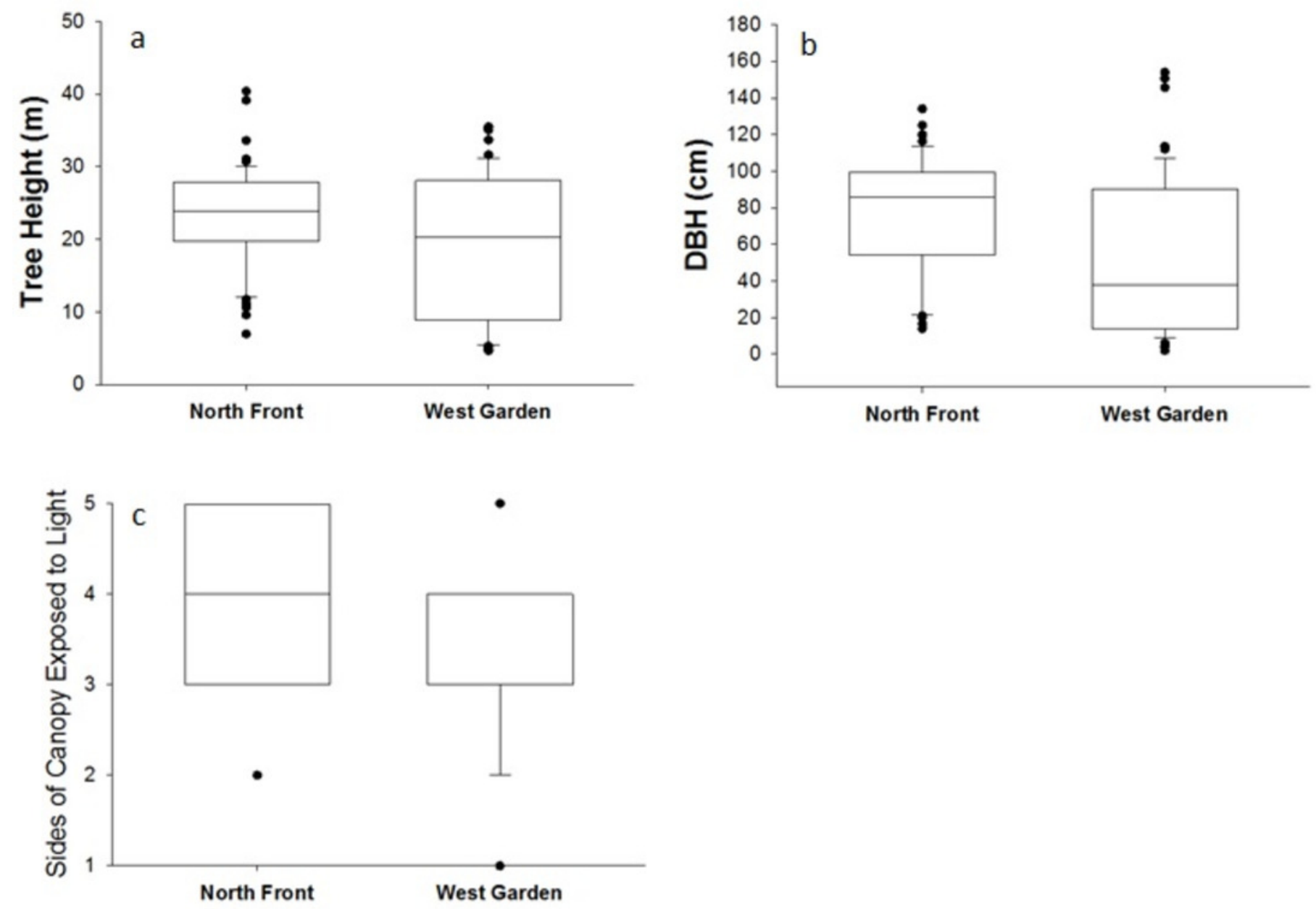
Figure 3

Size class distribution based on diameter at breast height (DBH) of trees in the North Front (black) and West Garden (grey), and City of London ([10] with London data provided by Treeconomics and Forest Research available at:

http://www.urbantreecover.org

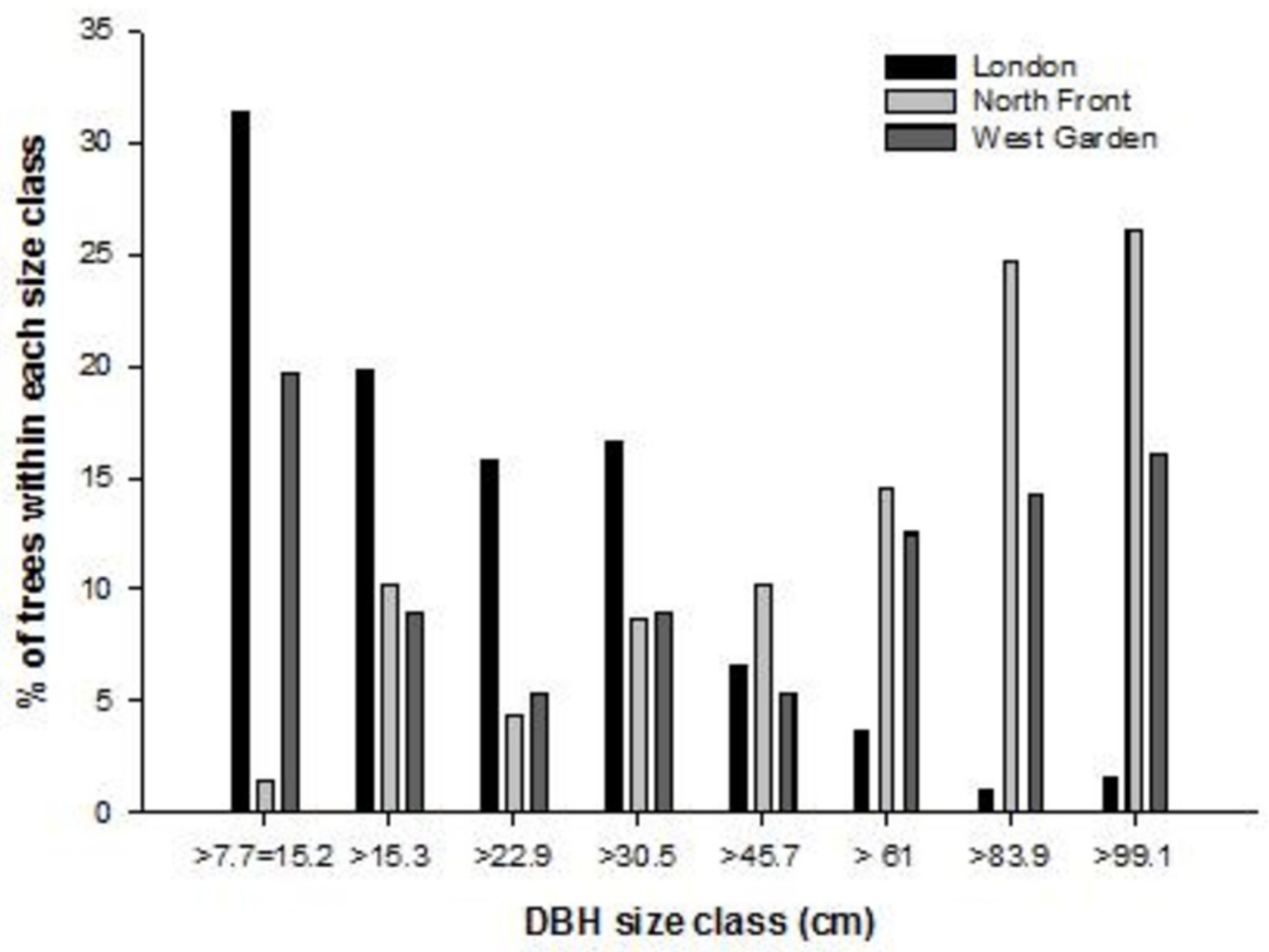

